\title{
Albanian Slide: The Roots to NATO's Pending Lost Balkan Enterprise
}

\author{
ISA BLUMI*
}

\begin{abstract}
Since the end of the 1990s, Albanians in North Macedonia, Albania, Kosovo, Montenegro, and Serbia have submitted to a regime of political and economic austerity in return for access to the European Union. The heavy costs, from economic decline, deadly pollution, and political corruption have translated into years of frustrations. These frustrations have exposed a political failure that extends from the region to the United States and Brussels. The resulting political turmoil will soon turn violent as the global economic downturn puts strains on Albanians sliding further away from their untrustworthy EU/U.S. allies. These afflicted relations may also highlight enduring tensions within the larger NATO alliance as American unilateralism continues to strain the divergent interests of key European partners.
\end{abstract}

Following the objections they face, the presidential initiative of Thaçi and Vučic for land swap needs incidents on the ground, new tensions and destabilization of the situation, to proceed. We hold them responsible for the violence that may occur. Albin Kurti, February 7, 2019

\section{Introduction}

T hings were looking good for a while. At least that is what both Albanians living in the Balkans and abroad were telling themselves. With laudatory reports from indigenous politicians and a growing social media infrastructure, it was hard not to share in the optimism. As they awaited integration into the European Union (EU), all the distinct Albanian constituencies (inhabiting North Macedonia, Albania, Kosovo, Preshevë, Medvegjë, and Bujanoc in Serbia, Montenegro, and the various adopted homelands overseas), exclaimed a pride and giddy self-assurance. The popular media in particular, be it Twitter or Albanian-language journals, offered plenty of evidence that the once feisty rhetoric of determined independence and nationalism had turned into a calming monotone of contentedness.

Of critical value was the apparent presence of Albanians -self-acknowledged or not- in the larger world. Albanians like Rita Ora, Bebe Rexha, and Dua Lipa top the music charts. Albanian sports stars win gold medals in Judo and score spectacular goals for the best football squads in the world. The best chef

* Stockholm University, Sweden

Insight Turkey Vol. 21 / No. 2 / 2019, pp. 149-170 
Beset by grinding

economic austerity

measures and structural

adjustments agreed to

by corrupt politicians

in the 1990s and 2000s,

Albanians throughout

the Balkans have not

seen a return for their

considerable material

and moral sacrifices in the world, the most beautiful model, the hottest club scene, undiscovered coastlines, and membership in NATO, all constituted acknowledgements of Albanians' place in the world. For a people long ignored by the critical institutions of power, even derogatory statements about just how evil the Albanian mafia, is constituted publicity that reassured Albanians. Until recently, Albanians throughout the world felt they had gained access (at the expense, some old Marxist rebels lamented, of basic principles), to the Western table.

Alas, Albanian delusions were no panacea to reality. Beset by grinding economic austerity measures and structural adjustments agreed to by corrupt politicians in the 1990s and 2000s, Albanians throughout the Balkans have not seen a return for their considerable material and moral sacrifices. They are beginning to openly protest these conditions. Students shutting down the streets of Tirana and Pristina are only the latest in a series of collective action protests against egregiously unfair relations. ${ }^{1}$ The growing popularity of those organizing the protests and the evidence of them turning violent, demands some introspection.

As with Kosovo's disgruntled population, in the Republic of Albania, integration into Europe required different, ever-expanding demands before actual accession negotiations began. Ongoing delays in the process have undermined previously reliable political alliances. ${ }^{2}$ In the two other countries with important Albanian populations, North Macedonia and Montenegro, similar turmoil has emerged as both populations see no clear path to joining the union. While both countries are now NATO members, as Albanians elsewhere can attest, surrendering control of a country's military capacities does not translate into a smoother path into the EU. ${ }^{3}$

The resulting protests ultimately point to a common failure in Brussels and Washington to reward the peoples of the Balkans for their sacrifices. Instead, they are now faced with what is likely a global recession, hitting their region the hardest. Albanians, like Bosnians, Serbs, and Greeks, observe incredulously a shift taken by Washington that hints at more economic austerity and less funding to maintain a modest national budget. These changes, lament commentators, will have regional political consequences. For one, there will likely be a bigger role for outspoken nationalists as they push to open the Pandora's box of Southeast Europe: the redrawing of national boundaries. ${ }^{4}$ 
The following explores how this anger, manifested among Albanians, could threaten regional stability, and once an anticipated global economic slowdown impacts the region, contribute to tensions within a NATO alliance forced to adapt. The resulting crisis will ultimately underwrite a new discourse about what various parties' interests are as a new generation of political actors evoking ethno-national agendas throughout Eurasia gain popularity.

\section{A Shift as Hopes Fade}

A sense that the "fight" has been truncated before the desired unification of Albanian lands has become an enduring if largely "in-house" problem within Albanian societies of the former Yugoslavia. ${ }^{5}$ Handing over their weapons in return for a NATO-imposed peace was a difficult concession for thousands of hardened fighters. They had spent the better part of the 1990s resisting Serbian/Macedonian rule and sacrificed far more than was ever acknowledged by the West. In this respect, many did not trust the new NATO hegemons. Bitter at NATO's ambiguous role in the 1990 wars, the suspicions of many Albanians had to be silenced. ${ }^{6}$ One solution was to turn former rebel leaders into politicians. $^{7}$

This tactic has not sat well with the men and women who have sacrificed so much. They openly admit they feel betrayed by those "hand-picked" by NATO to politically ease Albanians out of war. Indeed, the most successful "rebels" turned politicians -from Hashim Thaçi, Agim Çeku, Ramush Haradinaj in Kosovo, Ali Ahmeti, Ahmet Krasniqi, and Samidin Xhezairi in North Macedonia- have helped impose severe conditions on their constituencies to accommodate the demands from the Balkans' new European and American masters. ${ }^{8}$ The response to this political process of "decommissioning" rebel units has thus been blunt: those receiving political (and financial) rewards for cooperating with NATO have simply helped replace one colonial overlord with another. ${ }^{9}$

As will prove critical for the ensuing 20 years, Albanians were expected to surrender their economic sovereignty (something that Europeans themselves had seemingly agreed to with the creation of the EU). This was the agreed price Albanians would pay for a promised visa liberalization regime and a place in the community of nations. ${ }^{10}$ The problem for Albanians has been the seemingly never-ending demands made on them to "reform" politically. In the meantime, they have also been expected to surrender their considerable natural wealth to outsiders. ${ }^{11}$ As well-connected German, Israeli, and American companies loot their homelands, it is now clear that Albanians in large majorities believe the cost of surrendering of their political and economic sovereignty has been too high. ${ }^{12}$ 


\section{Albanians increasingly believe that EU authorities do not intend to grant them what was promised in 1999 in return for putting down their weapons}

media and in waves of large street protests speaks of an anticipated reversal of friendly relations with stingy EU/U.S. allies. ${ }^{15}$ Indeed, the tenor of the speeches via blowhorn that resonates in cities throughout the Western Balkans today suggests a population ready to abandon the mediating institutions and political, cultural elite the EU/U.S. installed in the late 1990s. Albanians, like their Serbian, Bosnian, Montenegrin, and Greek counterparts, have reached their limit, and in many explicit ways via their protests have alerted the world there will be consequences. Drawing on interviews and on-the-ground engagement with many of the primary operatives of this "spring-like" upheaval in the making, it is possible to predict that we have reached a point of no return.

\section{A Balkan Spring Awaits}

Albanians, via their re-animated opposition leaders, say that they have had to bend over backward to satisfy what is now understood to be insincere demands for "reform" in return for entry into the EU. ${ }^{16}$ Indeed, in Kosovo, the current political crisis discussed below is often framed in the context of the 95 different criteria being fulfilled to-date for the visa-free regime everyone seeks. From opposition leaders long hostile to the UN/NATO regime of compliance installed in the region since 1999 to the current prime minister, such burdens have destroyed hope. More critical today is the sense that this articulated sense of EU/U.S. betrayal came with the direct cooperation of now entrenched politicians, all of whom now face a populist backlash that will likely evolve into open revolts like those recently seen in Greece, France, and throughout the Middle East. ${ }^{17}$

Critically, unpopular politicians can stoke nationalist emotions and create new "facts" on the ground. Once pliable assets could simply switch from being the peacekeepers of the region to those upsetting stability. There is not much room left for Albanians to maneuver otherwise. As happened in the past, when cornered, Albanian survival tactics will ignite the larger Balkans. Adding fuel to the fire is the now public browbeating from Washington's newly installed neo-cons and corresponding, opportunistic belligerency from the neighboring Serbian leadership. ${ }^{18}$

Faced with what is now a clear move by neo-conservative factions in America to pre-empt new alliances China, Russia, or Turkey can build as locals respond 
Now that "democracy" has proven not to be a guarantee for Albanian security and economic stability, larger numbers throughout the Balkans have begun to operate outside the institutions established since the 1990s to IMF-induced programs running their predictable course, Albanians and others will have to revisit the recent makeshift efforts by the EU to delay their rightful place in Europe. ${ }^{19}$ The so-called "Roadmap for Visa Liberalization" established after a considerable debate in 2016, for example, provides ample proof for those arguing for a new direction. ${ }^{20}$ This imposed regime served as a temporary stopgap to what was

already in 2016 a period of open complaints from Albanians about the lack of commitment from Brussels. Predictably, this agreement has subsequently proven to be nothing more than one more pretext to indefinitely delay a final agreement on integration.

As articulated so well by a growing list of opposition political leaders, Albanians increasingly believe that EU authorities do not intend to grant them what was promised in 1999 in return for putting down their weapons. ${ }^{21}$ Compounding this anger is the larger context of a global economic crisis likely to ignite a wave of violent responses locally. Humiliated, impoverished Albanians realize there is no longer reason to bow to the ills of unfettered global capitalism; they demand back what NATO has taken away.

As throughout the Third World, vetted Albanian leaders have exposed their peoples' most valuable assets to the whims of "the market."22 The privatization of most of what had been state assets required that local "leaders" rip up laws that protected local industry, workers' rights and generous health, education, and social security programs. The adoption of policies that aimed to entice foreign direct investment (FDI) at the expense of Albanian well-being has proven especially disastrous to local societies. ${ }^{23}$ More, those same leaders so eager to capture the personal favor of the dons of the neoliberal era have also willfully sent men to do battle on behalf of NATO. The death of sons in Afghanistan, Syria, Iraq, or Central Africa is yet one more of the untold stories behind Albanian fury. The contradictions so evident to those left with a dead son is now being articulated collectively, to the ultimate detriment of relations between NATO and their valued Albanian partners. ${ }^{24}$

It is clear from conducting interviews over the last year that many on the ground in the Balkans now believe the costs have been too high. In their own words, it is a question of losing patience. After almost 20 years of brutal structural adjustments, Albanians, once fanatically loyal to Europe and the U.S., now believe the dream of becoming European has evaporated. ${ }^{25}$ As a result, Al- 
banians are now willing to listen to skeptics who have since the 1990s scoffed at the manipulative promises offered by Euro-American military, business, and political leaders. ${ }^{26}$ Once deemed overbearing zealots of a different era, political and social leaders like Albin Kurti have suddenly found a new audience. Mistrust of political parties and the "rule-of-law" regime that now clearly services the "interests of capital" and the utter lack of governmental oversight means that old socialist, anti-imperialist narratives are finding a new generation of partisans. $^{27}$

\section{America's New Cold War}

Now that "democracy" has proven not to be a guarantee for Albanian security and economic stability, larger numbers throughout the Balkans have begun to operate outside the institutions established since the 1990s. ${ }^{28}$ This distrust in the states that NATO built out of the collapsed regimes of the Cold War will mean the next few months and years may see Europe's Balkan nightmare becoming a reality. Perhaps the most dangerous factor for the short period moving forward is the realization that all the bowing to American and EU demands has not bought allies. ${ }^{29}$ As of mid-February 2019, the Americans, in collusion with some members of the EU (but critically not all, especially Germany), have reversed heretofore friendly cooperation with both Tirana and Pristina governments.

The tensions have come as hardliners in both the EU and the U.S., associated with sponsoring a new Cold War with Russia and/or China, want to see lingering disputes in the Balkans resolved, even if that entails redrawing maps. ${ }^{30}$ With leaders of fragmenting polities increasingly looking outside of NATO for support -to China, Russia, and Turkey in particular- the prospects of a forthcoming economic crisis in such diplomatic limbo promise unpredictable violence ahead. When yet another wave of brutal economic austerity measures awaiting already impoverished Albanians hits, the rapidly-changing rhetoric coming out of Washington, and some corners of the NATO alliance will give them few options.

Seemingly reversing an established guarantee to no longer redraw the Balkans' borders, recent arrivals to the White House are again promoting such dangerous, ethnic-based "land swaps." 31 Behind this change is the return of the notorious neo-conservatives to the White House in the form of Chief Security Advisor John Bolton. Better known for the aggressive policy towards Iran, China, and Venezuela, prior to Kosovar independence in 2007, Bolton had once advocated that the borders of the Balkans be redrawn to fit ethnic lines. To Albanians, and many European powers, especially the Germans, such "solutions" promote violence. ${ }^{32}$ 


\section{Albanians wave \\ flags from their cars on November 8, 2010 in Tirana to hail the EU decision to extend visa-free travel rights to them.

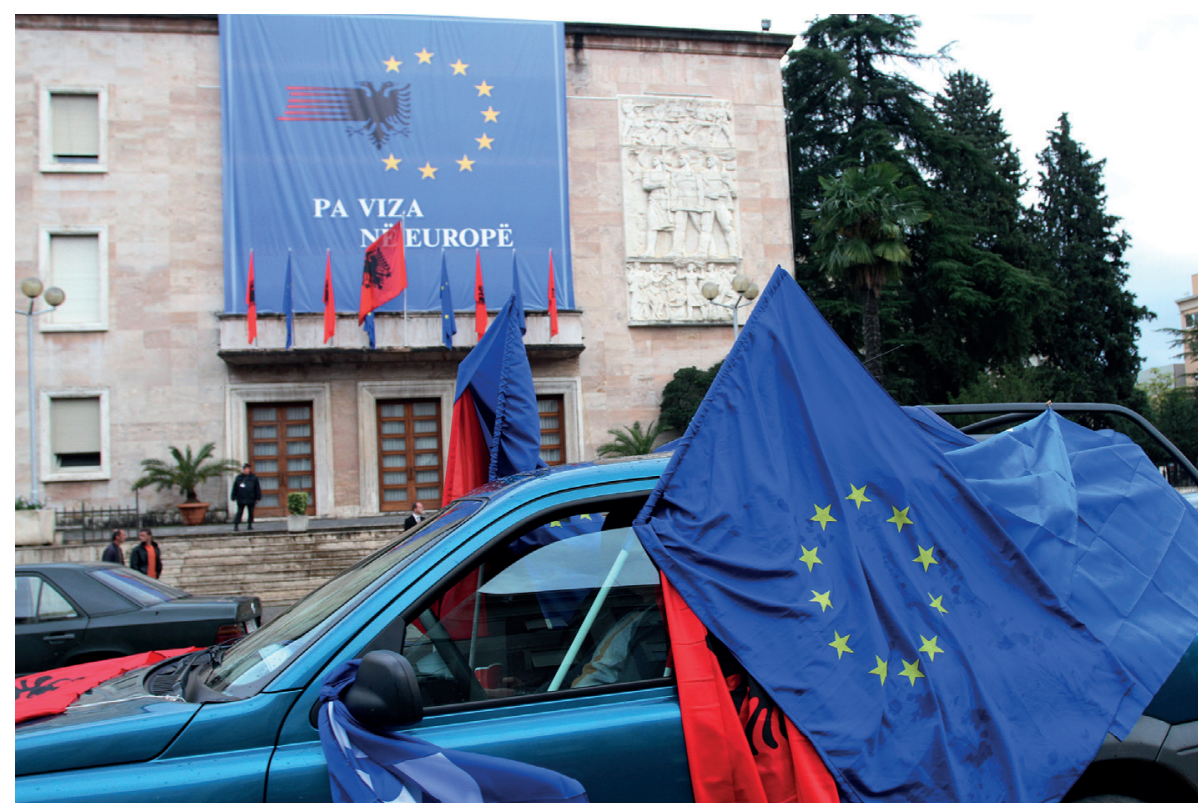

Already having surrendered 2,800 square hectares of prime forest land to Montenegro last year as a concession to EU/U.S. demands, today pliable (but largely unpopular) politicians associated with President Hashim Thaçi have again agreed to pursue negotiations, this time with Belgrade. ${ }^{33}$ What enervates the masses in Kosovo's streets today is the belief that, as in the case of secret negotiations with Montenegro, these largely unreported talks will lead to territory swaps. ${ }^{34}$ Thanks to leaks to the media, Albanians now know that Thaçi is being pushed to abide by the "International Agreement of Principles Governing the Normalization of Relations between Kosovo and Serbia" in ways that make "land swaps" the most expeditious way to end tensions. The problem is that NATO's favorite Kosovar politician and his team have little credibility. As these negotiations are being conducted in defiance of Thaçi's coalition partner, Prime Minister Ramush Haradinaj, and amid a population distrustful of Serbia's ruling party, there was little left to do but strike back with collective outrage. ${ }^{35}$

Kosovo's ruling coalition has parted ways. Haradinaj has responded with a clear intention of mobilizing an outraged population. His popular imposition of tariffs to protest Serbia's constant harassment of Kosovo internationally (recently blocking Kosovo's entry into Interpol and lobbying countries to reverse their recognition of Kosovo's independence) reflect a new willingness to confront former allies. ${ }^{36}$ This revolt in response to American unilateralism and EU intransigence is promising to create permanent political chaos in the Western Balkans. ${ }^{37}$ 
For the last year, European observers working for Brussels-based think tanks have, with the help of a newly trained generation of native scholars, noted a rising threat of "instability" coming from the Balkans. Framed in their reports as the pathological "ancient hatreds" that haunt the region, a palpable change in mood on the streets of the major Balkan cities from reluctant "tolerance" towards "ethnic others" in return for progress towards integration with Europe is noted. ${ }^{38}$ Impossible to ignore has been the uptick in violent rhetoric among increasingly unpopular public figures, not only directing vindictiveness at ethnic rivals but, more concerning

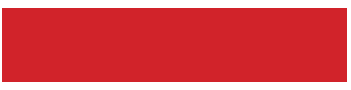
As the politicians of today struggle to remain relevant, they do so by doing the bidding of the EU/U.S. at the expense of their own people's interests still, the entirety of the EU/U.S. liberalist project in the Balkans. Largely closed out of a political system neatly designed since the 1990s to assure unobstructed "market" access to the region's economy, even once reliable Albanians are now voicing a mounting, well-articulated hostility toward Brussels and Washington. As Albin Kurti warns, this can get violent. ${ }^{39}$

As entrenched politicians/entrepreneurs go through the cycles of excusing themselves for the enduring injustices their constituencies have experienced since the 1990s, it may not take much more to ignite what has in France, Greece, and throughout the Middle East proven too much for either the EU or U.S. to handle. As with neo-liberal implants Macron in France or his Greek or Tunisian counterparts, economic stagnation and greater collective humiliation have undermined the legitimacy of politicians like Edi Rama, Hashim Thaçi, Alexander Vučić, and their entourages. ${ }^{40}$

Crucially, with their backs against the wall, all three leaders have proven capable of openly threatening to unleash violence if needed on their immediate political rivals, their population and finally, if necessary, ethnic others. In all three cases, once useful political coalitions linking like-minded larger political factions -especially in Kosovo where former soldiers in the Kosovo Liberation Army (KLA)- have proven untenable. As the politicians of today struggle to remain relevant, they do so by doing the bidding of the EU/U.S. at the expense of their own people's interests. This leads to necessary domestic alliances breaking apart. The Socialist Party of Albania, for instance, has split since the last elections in 2017 that brought Edi Rama into the position of prime minister and his erstwhile ally Ilir Meta to the Presidency. ${ }^{41}$ Today, Albania is in a constitutional crisis, as once favored Edi Rama finds himself and his close allies undermined by Meta and his new patrons in Brussels.

More dangerous still for the region is that the coalition which had brought together very different kinds of veterans of the wars in the 1990s in Kosovo 
(Thaçi and Haradinaj) has broken into rival factions, blocking each other's ability to govern. As noted above, the heart of the current crisis in Kosovo is a conflict over how to pursue a "dialogue" with Serbia over a formal end to their diplomatic deadlock. According to a now massive opposition, President Thaçi has used his close ties to the EU/U.S. to push entirely unacceptable concessions. ${ }^{42}$ According to critics, the "Association of Municipalities with a Serbian Majority" scheme proposed back in 2015 would create a legal possibility for hardline nationalists to acquire executive competences. ${ }^{43}$ As long argued, these moves threaten to undermine Kosovo's sovereignty in critical Northern and Central Kosovo regions. ${ }^{44}$ Prime Minister Ramush Haradinaj, having already paid the price for agreeing to surrender a large swath of Kosovar territory to Montenegro a year earlier, no longer has the political capital to continue playing to Washington's unpopular demands.

For their part, Belgrade's unrepentant Milošević-era layover regime has played hardball, shutting down negotiations until Haradinaj's government pushes this initial concession through Parliament. Paired with the paradigmatic shift in Washington led by Bolton, Kosovo's (and Albania's) leaders find themselves in a terrible position. As economic conditions, already dreadful in the region, and likely to deteriorate further with a global slowdown, the abrasive anti-Albanian policies promoted in Brussels, and open calls from Washington to pursue ethnic partition schemes will translate into worsening relations. ${ }^{45}$ Indeed, it is already clear that many in the region now believe that the long-promised integration will never materialize. The response is violence, directed at any number of enemies (new and old, domestic and foreign).

\section{The Western Balkans as Europe's Pandora's Box}

Critically, by stoking ethnic conflict with their neighbors, a much-abused gambit has secured greater leverage for Serbia's political elite in relation to Bosnia and Kosovo. This influence has been enhanced by the growing divisions within the NATO alliance in response to tensions with Russia. ${ }^{46}$ The possibility of renewed alliances with Turkey, Russia, or other rivals to the EU/U.S. project secures greater attention to Serbia, giving Belgrade leverage over Albanian-related issues. ${ }^{47}$

Alexander Vučić, head of state propaganda during the last years of the Milošević era, is no stranger to manipulating ethnic politics. ${ }^{48}$ Important here is that Vučić's Serbian Progressive Party's current (increasingly unpopular) leadership is not the only one using ethnic tensions to try to secure leverage in a rapidly shifting global order. Faced with a crisis caused in part by the lack of progress toward EU integration, Albania's Edi Rama has also tried to regain traction with Brussels by occasionally evoking Albanian issues in North Mace- 
donia and Kosovo.. ${ }^{49}$ Lastly, Kosovar politicians have also been compelled to take more popular positions. While Hashim Thaçi has remained willing to bend to whatever Washington/Brussels asks of him, his policies are logically forcing opposition (and even coalition partners) to take a greater nationalistic stand.

These seemingly different conjunctures of the contemporary Balkan crisis share a common thread that may warrant closer consideration. These Balkan politicians threatening instability if they are pushed out of favor also have strong ties with the likes of Tony Blair and the Clintons. Indeed, using tax-payer funds, all three leaders are paying big money to consulting firms with connections to those with a long history of instigating precisely the kind of violence awaiting the Western Balkans in the future. In short, the violence unleashed during the Blair/Clinton "Third Way" era seems to have a distinct possibility of returning to the same region in which these icons of neo-liberalism began their careers. ${ }^{50}$

While neo-conservative/neo-liberal operatives have likely developed their own formula to profit from any new war and incumbent destruction in the Balkans, career diplomats in Brussels have become notably uncomfortable with the prospect of their most reliable Albanian and Serbian interlocutors failing to subdue their respective populations. Most worrisome is Albania's Prime Minister Edi Rama's threat to unleash ethnic conflict if concessions are not given, which resulted in a direct counter-offensive supported by the EU and Washington throughout 2018 to undermine Rama's government. ${ }^{51}$

Using their media infrastructure to apply pressure on their erstwhile subordinates, sources based in Brussels have whispered to reporters that Albania's Edi Rama, once the West's most popular intermediary in the region, could find himself voted out of power or face defections from his Socialist Party. ${ }^{52} \mathrm{His}$ sin? The charismatic former mayor of Tirana, believing he has Tony Blair, Alastair Campbell, and powerful Israeli property developers behind him, has wondered aloud how much further he could do the EU's bidding in respect to imposing draconian austerity and devastating structural reforms on his population. ${ }^{53}$ This open question enervated already tense negotiations behind closed doors. That Rama would publicly follow up such questions with making "dangerous" overtures to neighboring Kosovar and Macedonian-Albanians has exposed a 
The captured states in which most Albanians in the Balkans live today have remained servile to the EU/U.S. order thanks to the methods applied universally by international organizations since the 1990s, ubiquitous in the region growing rift between Brussels and Tony Blair's protégé. ${ }^{54}$ It also suggests when once mutually-beneficial relations become tested, the predictability of former allies can suddenly prove misinformed.

At the heart of the problem is that Rama, expected to subdue his country regardless of the pain EU "reforms" bring it, can no longer sustain his constituent base. Every time

EU officials have brought a new set of demands for more painful "reforms," Rama's outraged supporters, expecting clarity on when promises of integration (and thus right of travel) would bear fruit, have lashed out at his government. ${ }^{55}$ Reaching the heights of prime minister with the promise of Albania's full integration into Europe as his platform, reality has struck home for most of Albania's youthful population. While the country seems to have thrived while Tirana became Europe's hippest weekend party town, the pressures put on most Albanians have undermined Rama and the Socialist Party (PSSH) he represents. ${ }^{56}$

Ruling for almost a decade without opposition, the PSSH is fragmenting, with Ilir Meta, the country's president, and former party member, openly challenging Rama's leadership. ${ }^{57}$ Meta, like many other politicians and civic leaders until recently coerced to remain quiet, have taken a stand behind massive student protests against the economic austerity imposed on them and their families. ${ }^{58}$ Rama has been left no choice but to use his ethnic card.

These events have followed a difficult 2018 in which Rama and his EU allies have clearly diverged. In the face of the ire of his constituency responding to corruption and failed promises about progress towards integration, Rama has started to quietly threaten to use leverage among Albania's neighbors to cause larger regional tension. ${ }^{59}$ From inviting all of North Macedonia's Albanian parties to discuss behind closed doors strategies in their struggle with Skopje to suggesting talks with Kosovar leaders about a union with the controversial neighboring Albanian state, Brussels reacted accordingly ${ }^{60}$ Brussels now accuses Rama of stoking ethno-nationalism in neighboring North Macedonia and even threatening to go ahead with negotiations to unify with Kosovo, where an equal number of Albanians live in a sequestered NATO/UN created quasi-state. ${ }^{61}$ Clearly breeching the limits as to how Albanians could engage the consequences of their brutal integration into the North Atlantic dominated "global economy," the floundering relationship between Brussels and Rama has its Kosovar version as well. 


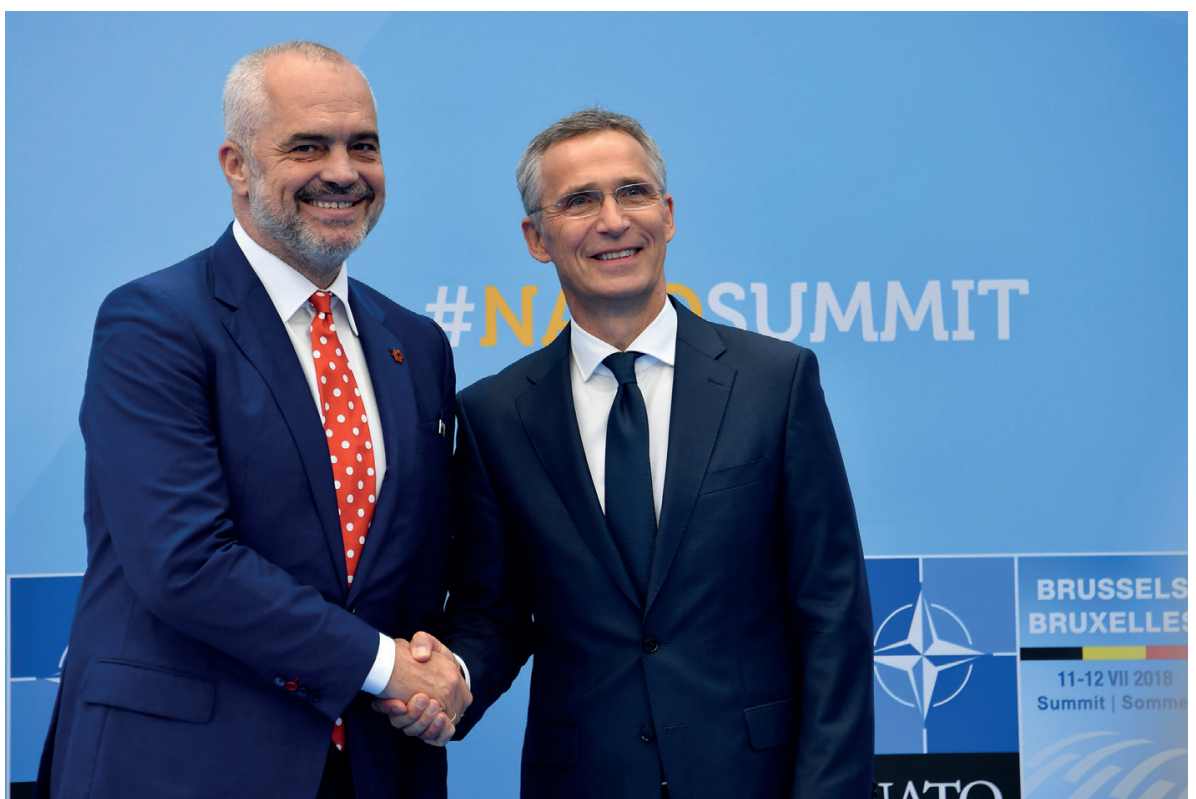

Unlike Albania, which has been formally acknowledged as a future candidate, Kosovo's two million inhabitants are trapped by a Stabilization and Association Agreement with Brussels. ${ }^{62}$ For 15 years now the EU has harassed Kosovar Albanian politicians to cut social programs and crack down on what they assumed were criminal networks while imposing a legal and institutional framework that ultimately served only predatorial EU/Israeli-backed companies. ${ }^{63}$ Demands of "legal reform" especially have been read as invasive "free trade" mechanisms that undermine Albanian economic independence. ${ }^{64}$ Worse still, Kosovo's politicians are forced to enter into negotiations with Serbian officials regardless of the often racist political platforms Belgrade adopts. ${ }^{65}$

Ever since NATO's 1990s interposition into the Balkans, skeptical individuals would confide anger about the foreigners' interventions over a quiet coffee. Unleashed by the opportunities of war, overtly liberal projects were criticized for being stealth agendas to access previously guarded wealth with only friendly politicians able to profit from the structural changes. ${ }^{66}$ After years of hollow assurances, these early iterations of mistrust are now finding collective traction in once easily-suppressed polities. This acknowledgment of NATO's betrayal to secure long-term national interests by publicly declared allies, Albanians of all affiliations have realized the extent of their marginalization in the larger European context. It looks bad from the perspective of those living in the Balkans. The bullying of Albanian politicians, often using overt blackmail, accompanied by snide insinuations that they are not quite civilized enough, has cut a new line of collective resentment in a large swath of Albanian societies. As they
Albanian PM Rama

(L) shakes hands with NATO Secretary General Stoltenberg (R) during the NATO summit, at the NATO headquarters on July 11, 2018.

DENIS CHARLET / AFP / Getty Images 
increasingly fear the consequences of what seems to be a pattern of expected public subordination, so too will the old spirit of resistance cultivated by decades of living under oppression in Yugoslavia, take its most productive, and perhaps most dangerous form. ${ }^{67}$

\section{Conclusion}

Albin Kurti's warning that begins this piece is not hyperbole. It is based on experience and reflects the man's well-proven capacity to understand the street. His allies aim to capitalize, riding a wave of renewed popularity (his anti-elite Lëvizja Vetëvendosje party is now Kosovo's most popular) and hints at efforts to explicitly pressure the entrenched leaders of the current coalition, including President Hashim Thaçi, long Kosovo's Prime Minister and leader of the Democratic Party of Kosovo (PDK). Similar machinations are at work in neighboring Albania, with the Socialist Party's fragmentation and open protests in the street threatening much invested objectives. What this reflection on the current and immediate future state of Albanian affairs in the Balkans warns is that Kurti is not only right to read into his interlocutors' frustrations: he will prove prophetic.

The captured states in which most Albanians in the Balkans live today have remained servile to the EU/U.S. order thanks to the methods applied universally by international organizations since the 1990s, ubiquitous in the region. ${ }^{68}$ The results have been continued economic disparities, lingering threats, and sometimes overt acts of ethnically-motivated violence. ${ }^{69}$ Mediating this persisting violence has long been the promise that, if properly integrated, Albanians could at least travel freely. As evidenced by years of a "process" seemingly losing the sedated compliance of a larger population left waiting, that reprieve from overt Albanian anger is ending. ${ }^{70}$ Desperation has set in with the now fully entrenched political elites incapable of providing the internal resistance their people so desperately need in the face of European-American hypocrisy and lies.

It is now revealed that even the most untouchable ally of them all, the United States, is turning its back on Kosovar Albanians. While the U.S. embassies throughout the region continuously browbeat any semblance of disloyalty, they have begun to deny Albanians visas, cancel training programs for soldiers, and mobilize their social activist assets to apply pressure on the streets. Crucially, even those reliable Washington-supported activists are now beginning to see the truth. The rise of the neo-conservative/Clinton alliance that utters Cold War-era threats has shown the true colors of a capitalist empire now facing structural challenges largely unannounced in academic and media sources. And this is where we must read the Western Balkans' percepti- 
ble slide toward violence as part of the larger struggle for the last bits of liquidity. The Western Balkans are up for sale. Kosovo's still heavily-desired mineral assets will necessarily become available to global capital by way of competing claims of ownership. ${ }^{71}$ Natural Gas pipeline politics, the same that destroyed Syria and Iraq, and smashed the Balkans in the 1990s, are in play again. Albanians have not eloquently shifted to reflect
The possibility is there for other Albanian communities, facing similarly exploitative relations with the global capitalist project, to seek cross-border alliances that will introduce new domestic and regional politics

the mailability one must show in order to have leverage in the process of allocating who wins and loses. They thus run the risk of becoming Greece, a country ravaged by the vultures of (disaster) capital, increasingly hungry for sustaining liquidity. ${ }^{72}$

This poverty translates into resentment that finds its initial articulation through the political skills of Albin Kurti and his Lëvizja Vetëvendosje..$^{73} \mathrm{~A}$ party built on vocal protests against NATO back in the 2000s, it has regained a foundation for a new era of public action. ${ }^{74}$ In an era where heroes fight zombies and vampires, Kurti's platform of polemic is growing again, with an always curious Western audience accompanied now by a new generation of politically frustrated Kosovar Albanians. ${ }^{75}$ As Kurti has long claimed, reconciliation, the need to "negotiate," has proven the failsafe tool to assure that Albanians never challenge the West. Those who robotically evoke this mantra cannot be trusted with Albanians' future. ${ }^{76}$ This means that Albin Kurti's ability to mobilize is both real and likely to be far more effective in upsetting Albanian relations with the rest of the world as his growing cadre of supporters abandon those whom NATO could once expect to keep their constituencies from sliding away.

The possibility is there for other Albanian communities, facing similarly exploitative relations with the global capitalist project, to seek cross-border alliances that will introduce new domestic and regional politics. What may induce this process to become strategically aggressive will be the economic collapse of what barely sustains Albanian communities today. This re-animation of Albanian polities has been long overdue, but will likely face a violent response as deadly, if not more so, than what we have witnessed in the past. With the possible outbreak of war in the Balkans a result of growing rivalries inside and beyond the region, the growing evident tensions within the NATO alliance may manifest as countries with distinctive strategic concerns, like Germany, finally pursue a policy vis-à-vis Eastern Europe that services their cooperation and security needs, rather than those of Washington. 


\section{Endnotes}

1. For an excellent history of youth activism in Kosova see, Dafina Halili, "Three Decades of Protest," K2.0, (March 9, 2018), retrieved February 12, 2019, from https://kosovotwopointzero.com/en/three-decades-protest/.

2. In April 2019, in response to public "outrage" spurred on by stories of Albanian mafia activities in the country, the Dutch Parliament voted to "reintroduce" rigid visa requirements for Albanian citizens. Gjergj Erebara, "Dutch Vote to Reintroduce Visas Alarms Albania," BIRN, (April 17, 2019), retrieved from https:// balkaninsight.com/2019/04/17/albania-and-eu-delegation-downplays-dutch-vote-for-visa-reintroduction/. The move reminded many of the difficult 1990s that left post-Communist Albania isolated, poor, and fragile. Lumnis Çela, "Mapping Albania's Path in the 1990s: Between Authoritarianism and Democratisation," European Journal of Interdisciplinary Studies, Vol. 4, No. 2a (2018), pp. 162-166.

3. The process of integration into the NATO mechanisms was promised to be the first step toward access to the EU. Albanians' surrender of all military autonomy to NATO required absolute subordination and a once formidable military was dismantled. Ryan C. Hendrickson, Jonathan Campbell, and Nicholas Mullikin, "Albania and NATO's "Open Door" Policy: Alliance Enlargement and Military Transformation," Journal of Slavic Military Studies, Vol. 19, No. 2 (2006), pp. 243-257.

4. The greatest risk comes from Bosnia, a country likely to be directly impacted by the manner in which Europe fends off Washington's new interest in redrawing the Western Balkans' maps. See, Srecko Latal, "'Dayton 2' Debate, Serbia-Kosovo Talks Reflect Balkans Spiraling Out of Control," BIRN, (February 12, 2019), retrieved from https://balkaninsight.com/2019/02/12/dayton-2-debate-serbia-kosovo-talks-reflect-balkans-spiralling-out-of-control/.

5. Frances Trix, Kosova: Resisting Expulsion and Striving for Independence, (Cambridge: Cambridge University Press, 2010).

6. Nicolas Lemay-Hébert, "Coerced Transitions in Timor-Leste and Kosovo: Managing Competing Objectives of Institution-building and Local Empowerment," Democratization, Vol. 19, No. 3 (2012), pp. 465485.

7. Elena Pokalova, "From Separatism to Terrorism and Back: The Case of Kosovo and the KLA," in Glen Duerr (ed.), Secessionism and Terrorism: Bombs, Blood and Independence in Europe and Eurasia, (New York: Routledge, 2018), pp. 101-118.

8. For some insight into a process in which pliable fighters were rewarded with a seat at the political table (and protection for the implicit threat of prosecution if they resisted) see, for instance, Robert Hislope, "Between a Bad Peace and a Good War: Insights and Lessons from the Almost-War in Macedonia," Ethnic and Racial Studies, Vol. 26, No. 1 (2003), pp. 129-151; Giorgos Triantafyllou, "Statehood Without an Army: The Question of the Kosovo Armed Force," Southeast European and Black Sea Studies, Vol. 18, No. 2 (2018), pp. 261-279.

9. At the time this settlement took place I provided several critical assessments of the newly victorious NATO powers' objectives in the Balkans. Isa Blumi, "One Year of Failure in Kosova: Chances Missed and the Unknown Future," South Eastern European Politics, Vol. 1, No. 1 (Summer 2000), pp. 15-24; Isa Blumi, "Outside the Foreseeable Future: The Tyranny of Ethnicity Politics in Kosova," The Anthropology of East Europe Review, Vol. 19, No. 1 (Spring 2001), pp. 109-127; Isa Blumi, "Kosova: From the Brink - and Back Again," Current History, Vol. 100, No. 650 (November, 2001), pp. 15-20.

10. Mirela Bogdani and John Loughlin, Albania and the European Union: The Tumultuous Journey towards Integration and Accession, $4^{\text {th }}$ Edition, (London: IB Tauris, 2007).

11. In February 2007, the hand-picked UN representative imposed on post-war Kosovo to administer the disputed territory, Finnish diplomat Maarti Ahtisaari, drew up a constitution that required the division of the country's political and economic institutions along Serbian/Albanian lines. This "Comprehensive Proposal for the Kosovo Status Settlement" aimed to secure protections for enclaves of Serbian communities who as late as March 2004 were vulnerable to attack by groups seeking to expedite (or undermine) the finalization of Kosova's "status." Frustrations about the deliberate attempts by various parties to undermine Kosovo's bid for independence translated into outrage when Ahtisaari's plan went public. In protesting this virtual redivision of Kosovo into ethnic enclaves, Kosovars took to the streets. 
The idea that Kosovo would become fragmented by tiny enclaves of "ethnic minorities" was a recipe for permanent turmoil. The vocal protests to stop this program were confronted by UN/EU-sanctioned violence. On February 11, 2007, two Kosovar protesters were murdered by Romanian forces ordered to suppress the protests. Most nationalists understand this empowerment of an ethnic criteria to distribute power as a plan to guarantee Kosovo's instability. It essentially continues policies instilled for decades by Serbian officials bent on discriminating against Albanian/Muslim/Catholic communities in Yugoslavia. The current turmoil in the Balkans is in large part a result of a program initiated by the Trump Administration to reintroduce this formula for the region. Oisín Tansey, "Kosovo: Independence and Tutelage," Journal of Democracy, Vol. 20, No. 2 (2009), pp. 153-166.

12. The consequences of unfettered access to Kosovo's considerable mineral wealth have been evident for a decade at least. As foreign companies plunder Kosova's mines, they have left behind costly environmental disasters to future generations. Alketa Bucaj, "The Impact of FDI in Mining on Kosovo's Economic Growth," International Journal of Academic Research in Business and Social Sciences, Vol. 8, No. 1 (2018), pp. 266-292; Avdulla J. Alija, Fisnik Asllani, Ismet D. Bajraktari, Andrew Richard Collins, Shemsedin Dreshaj, Nikolaus Bresgen, and Peter M. Eckl, "Atmospheric Pollution in Kosovo Is Associated with Increased DNA Damage in the Human Population," Biomonitoring, Vol. 2, No. 1 (2015), pp. 35-41.

13. Much of the scholarship to-date has presented Albanian youth, in Albania and Kosova alike, as generally more content with their relationship with the EU and the direction their political classes were leading them. Misleading studies citing relative numbers of support for recent political conditions in Albania, North Macedonia, and Kosovo no longer prove convincing upon considering the violent activities of youth groups in these countries over the 2018-2019 period. See, Dane Taleski and Bert Hoppe, "Youth in South East Europe," Human Rights, Vol. 24, No. 2 (2015), pp. 195-209, which noted a feeling of unease already in 2015. For instance, "only 17 percent of youth in SEE are satisfied with the state of democracy, and 38 percent are not satisfied... youth trust in their national parliament or government... in Kosovo [was] roughly one-third." [p. 197].

14. Helping to draw up formulas for selling off "inefficient" local companies, integrating Albanians' "undeveloped" economies and cooperating with globalist forces to impose draconian austerity has been a requirement for youthful would-be Albanian leaders. Following a template of indoctrination throughout the world, as evidenced by the Arab Spring and previous Balkan youth-led advocacy groups like OTPOR promoting neoliberal values, especially "democracy" and LBGT rights, Kosovo, Albania and the larger Western Balkans have become heavily divided societies thanks to these NED, USAID and British Council-funded programs. The realized class divisions between "educated" urban-dwelling English-speaking Albanians and their "backward" (katundar/e) countrymen will likely result in violent retribution if the socio-economic instability grows. Olena Nikolayenko, "Origins of the Movement's Strategy: The Case of the Serbian Youth Movement Otpor," International Political Science Review, Vol. 34, No. 2 (March, 2013), pp. 140-158; Jacob Phillipps, "The Role of Epistemic Communities: Local Think Tanks, International Practitioners and Security Sector Reform in Kosovo," Southeast European and Black Sea Studies, Vol. 18, No. 2 (2018), pp. 281-299; Sheila Carapico, "Foreign Aid for Promoting Democracy in the Arab World," The Middle East Journal, Vol. 56, No. 3, (2002), pp. 379-395.

15. Pellumb Kelmendi and Andrew Radin, "UNsatisfied? Public Support for Postconflict International Missions," Journal of Conflict Resolution, Vol. 62, No. 5 (2018), pp. 983-1011.

16. Deniz Mutluer and Dimitris Tsarouhas, "EU Foreign Policy and 'Perceived Coherence': The Case of Kosovo," Southeast European and Black Sea Studies, Vol. 18, No. 3 (2018), pp. 419-438.

17. Recent surveys support this conclusion that Albanians, among others in the Western Balkan "ghetto," have reached a breaking point. Sabiha Shala and Andi Belegu, "Visa Liberalisation Process in Western Balkans Countries Aspiring to Join the European Union," Management, Vol. 16, (2018), pp. 83-95.

18. Misha Savic, "U.S. Pressures Kosovo Over Stalled Talks with Serbia," Bloomberg, (February 13, 2019), retrieved from https://www.bloomberg.com/news/articles/2019-02-13/u-s-puts-pressure-on-kosovoover-stalled-talks-with-serbia.

19. Srecko Latal, "Failing Public Companies Imperil Bosnia's Stability, IMF Warns," BIRN, (February 18, 2019), retrieved from https://balkaninsight.com/2019/02/18/failing-public-companies-imperil-bosnias-stability-imf-warns/. 
20. European Commission, "Report from the Commission to the European Parliament and the Council: Third Report on Progress by Kosovo* in Fulfilling the Requirements of the Visa Liberalisation Roadmap," (COM-2016 276 Final, Brussels, May 4, 2016).

21. The EU has reneged on promises to set a firm date toward visa liberalization. While the conditions (and pretexts) are different for Albania, North Macedonia, Montenegro, and Serbia, how this process has played out in Kosovo is emblematic of a larger problem soon to explode. EU official excuses for the last year has been that Kosovar politicians have yet to provide the following improvements: addressing organized crime and corruption, the ratification of the agreement for demarcation of the Montenegro and Kosovo border, and the improvement of relations between Kosovo and Serbia through dialogue mediated (code for controlled) by EU institutions. A recent study has demonstrated that Albanians have lost their patience with such constantly shifting demands. Artjoms Ivlevs and Roswitha M. King, "Kosovo - Winning its Independence but Losing its People? Recent Evidence on Emigration Intentions and Preparedness to Migrate," International Migration, Vol. 53, No. 5 (2015), pp. 84-103.

22. James Ferguson, Global Shadows: Africa in the Neoliberal World Order, (New York: Duke University Press, 2006).

23. Johannes Sauer, Matthew Gorton, and Sophia Davidova. "What Drives Rural Out-Migration? Insights from Kosovo," Post-Communist Economies, Vol. 31, No. 2 (2019), pp. 200-217.

24. Elvin Gjevori and Gezim Visoka, "Albanian Peacekeepers: Exploring the Inward-Looking Utility of International Peacekeeping," International Peacekeeping, Vol. 23, No. 4 (2016), pp. 513-539.

25. Claire Gordon, “The Stabilization and Association Process in the Western Balkans: An Effective Instrument of Post-conflict Management?" Ethnopolitics, Vol. 8, No. 3-4 (2009), pp. 325-340.

26. Such a clear turn has infuriated Kosovo's most ardent supporters in the EU, particularly Germany. A contentious relationship with a Washington overlord willing to increasingly demand more economic sacrifices from Germany to sustain NATO's aggressive expansion eastward has its consequences in Kosovo. Moreover, the Trump Administration's trade-war policy exposes Germany, whose export-driven economy is losing out as countries adopt protectionist counter-actions. More crucially, a stable Balkans is critical to assure the cheaper energy offered by good relations with Russia and Turkey. As global economic shifts continue, the Balkans will prove the critical backdrop to a larger strategic divergence within NATO as Germany and Eastern Europe seek a new relationship with Eurasian powers. Andreas Maurer, "Germany and the EU: Managing Differentiation to Avoid Structural Segregation," in Michael Kaeding, Johannes Pollak, Paul Schmidt (eds.), The Future of Europe: Views from the Capitals, (New York: Palgrave Macmillan, 2019), pp. 41-44.

27. By design, it is virtually impossible for the Republic of Kosovo's government to function because of a multi-layered polity with conflicting associations by way of citizenship rights, a by-product of the UN-imposed "settlement" in 2007. Gëzim Krasniqi, “Overlapping Jurisdictions, Disputed Territory, Unsettled State: The Perplexing Case of Citizenship in Kosovo," Citizenship Studies, Vol. 16, No. 3-4 (2012), pp. 353-366.

28. Bilge YabancI, "The (II)legitimacy of EU State Building: Local Support and Contention in Kosovo,"Southeast European and Black Sea Studies, Vol. 16, No. 3 (2016), pp. 345-373.

29. Arolda Elbasani, "EU Enlargement in the Western Balkans: Strategies of Borrowing and Inventing," Journal of Southern Europe and the Balkans, Vol. 10, No. 3 (2008), pp. 293-307.

30. Eva Jovanova, “Redrawing the Borders between Kosovo and Serbia: Nationalists' Fuel or a Rational Solution with the Promise of a European Future?" International Journal on Rule of Law, Transitional Justice and Human Rights, Vol. 9, No. 9 (2018), pp. 111-119.

31. Jasmin Mujanović, "A Strategic Review of BiH's Bilateral Relations with the Major Powers," in Jasmin Hasić and Dženeta Karabegović (eds.), Bosnia and Herzegovina's Foreign Policy Since Independence, (Cham: Palgrave Macmillan, 2019), pp. 163-183.

32. National Security Advisor John Bolton, linked to a neo-conservative cadre built in the 1970s that sought to stoke the flames of ethnic, racial, and sectarian conflict to serve American imperialist agendas, has long advocated partitioning the Balkans along ethnic lines. More still, the use of ethnicity and sectarian associations, which necessarily means violently imposing ethnically "pure" areas, was part of 
U.S. policy. Michael Rossi, “Partition in Kosovo Will Lead to Disaster,” Foreign Policy, (September 19, 2018), retrieved from https://foreignpolicy.com/2018/09/19/partition-in-kosovo-will-lead-to-disaster-serbiavucic-thaci-mitrovica-ibar/.

33. "Strategy for the Western Balkans, 2018," European Commission, (February 6, 2018), retrieved April 22, 2019, from https://ec.europa.eu/commission/news/strategy-western-balkans-2018-feb-06_en.

34. A drawn-out process that exposed the largely undemocratic process in which Kosovo's relations with neighbors are formed, after months of effort by Albin Kurti's allies to stop the imposition of a drawing of boundaries with Montenegro, enough pressure was put on Parliamentarians and Judges to approve the deal. See, Die Morina, "Kosovo Govt Frets as Montenegro Deal Vote Nears," BIRN, (March 20, 2018), retrieved from https://balkaninsight.com/2018/03/20/kosovo-to-vote-the-controversial-agreement-demarcation-timeline-03-19-2018/.

35. Robert Muharremi, "The Fallacies of 'Border Adjustment' Between Kosovo and Serbia: Private Dealings behind Closed Doors are a Recipe for Future Conflict," K2.0, (September 3, 2018), retrieved from https://kosovotwopointzero.com/en/the-fallacies-of-border-adjustment-between-kosovo-andserbia/.

36. Blerta Begisholli, "Tariff Threatens Kosovo's Most Important Alliance," BIRN, (February 15, 2019), retrieved from https://balkaninsight.com/2019/02/15/tariff-threatens-kosovos-most-important-alliance/.

37. Arta Sopi and Die Morina, "Splits over Serbian Taxes 'Damage' Kosovo," BIRN, (January 21, 2019), retrieved from https://balkaninsight.com/2019/01/21/kosovo-politicians-differing-stances-on-taxesdamaging-to-the-dialogue-01-18-2019/.

38. John M. Nomikos and A. Th. Symeonides, "Intelligence and Balkan Instability: Repeating the Past or Moving in a New Direction?" International Journal of Intelligence and CounterIntelligence, Vol. 31, No. 1 (2018), pp. 85-101.

39. The most reported incident was Prime Minister Edi Rama's threat that Albania could at any time begin a process of unification with Kosovo, upsetting the "stabilization" EU/U.S. interests have imposed on the Balkans since the late 1990s. The visceral response from Brussels proved informative. Edi Rama has since faced considerable pressure, often via media outlets and well-funded public protests; his political future seems no longer guaranteed. "Leader of Opposition in Albania Demands the Country's Prime Minister to Step Down," Independent Balkan News Agency, (February 13, 2019), retrieved from https://balkaneu.com/leader-of-opposition-in-albania-demands-the-countrys-prime-minister-to-stepdown/.

40. Alida Vračić, "'1 in 5 Million': Mounting Pressure in Balkan Protests," European Council of Foreign Relations, (January 15, 2019), retrieved from https://www.ecfr.eu/article/commentary_1_in_5_million_mounting_pressure_in_balkan_protests; Die Morina, “Calls Grow in Kosovo for 'Border Correction' Protests," BIRN, (August 31, 2018), retrieved from https://balkaninsight.com/2018/08/31/kosovo-vetevendosje-warns-protests-for-next-week-08-31-2018/.

41. Fatjona Mejdini, "Albania Resolves Political Crisis with Election Deal," BIRN, (May 18, 2017), retrieved from https://balkaninsight.com/2017/05/18/albania-resolve-crises-with-parties-pledging-to-enterelections-05-18-2017/; Edison Kurani, "Political Crisis in Albania Deepens, the President and Prime Minister Exchange Strong Accusations," Independent Balkan News Agency, (January 11, 2019), retrieved from https://balkaneu.com/political-crisis-in-albania-deepens-the-president-and-prime-minister-exchangestrong-accusations/.

42. The tension between Haradinaj and Washington has led an opportunistic Thaçi, eager to demonstrate his loyalty to the U.S., to publicly chastise Kosovo's Prime Minister about his tactics. The fundamental role of politicians in Kosovo, according to this current dispute is to abide by Washington's dictates, no questions asked. "Thaçi Shton Presionin Ndaj Haradinajt: Taksa Duhet Pezulluar," Blic Gazeta, (February 17, 2019), retrieved from https://gazetablic.com/thaci-shton-presionin-ndaj-haradinajt-taksa-duhet-pezulluar/. According to sources, it seems that in critical meetings with the EU minister in Munich between February 15 and 17, Haradinaj received more than silent support from crucial EU members, including Germany, Croatia, and the Netherlands in respect to these tensions. Kosovo's political class is clearly divided, and their divisions are exposing the extent to which Washington's aggressive pursuit of territorial swaps has further antagonized Germany and others. 
43. Adem Beha, "Disputes Over the 15-point Agreement on Normalization of Relations between Kosovo and Serbia," Nationalities Papers, Vol. 43, No. 1 (2015), pp. 102-121; Cemaliye Beysoylu, "Implementing Brussels Agreements: The EU's Facilitating Strategy and Contrasting Local Perceptions of Peace in Kosovo," Southeast European and Black Sea Studies, Vol. 18, No. 2 (2018), pp. 203-218.

44. Michael Rossi, "Ending the Impasse in Kosovo: Partition, Decentralization, or Consociationalism?" $\mathrm{Na}$ tionalities Papers, Vol. 42, No. 5 (2014), pp. 867-889.

45. The Americans under a new strategic framework dictated by Bolton's team has resorted to crude bullying that has given Belgrade the greenlight to retain their most obstinate position vis-à-vis "land swaps." On February 12, 2019, in an effort to pressure Haradinaj's fragile government to reverse tariffs currently imposed on Serbia, a letter directed to key members of the Kosovar political elite was publicly released by the U.S. embassy. In it, U.S. diplomat Palmer states: "It's incredible that Kosovo values our friendship so lightly as to ignore our advice." The tactics are likely to pressure a reversal of policy, thus allowing Thaçi to continue to pursue the desired territorial revision of the Balkans. But these expositions of EU/U.S. policies have infuriated Albanians. For the entire text and commentary from a local newspaper see, "US Diplomats on Tariffs," Gazeta Express, (February 12, 2019), retrieved February 15, 2019, from https://www.gazetaexpress.com/en/news/us-diplomats-on-tariffs-it-s-incredible-that-kosovo-valuesour-friendship-so-lightly-as-to-ignore-our-advice-174885/.

46. Emre Erşen and Mitat Çelikpala, "Turkey and the Changing Energy Geopolitics of Eurasia," Energy Policy, Vol. 128, (2019), pp. 584-592.

47. The resulting divisions on the global stage have their regional consequences for once secure relations between Albanians, Bosnians, and Turkey. Ankara's clear shift toward strong relations with Serbia (for strategic calculations beyond the scope of this paper) has led to growing concerns in Bosnia and Herzegovina and Kosovo that a once-reliable alliance has shifted. The consequences of public tensions between Pristina and Ankara are likely to lead to the further isolation of Albanians, whose unprincipled blind allegiance to the U.S. has translated into an unnecessary chilling of ties with Turkey. Daniel McLaughlin, "Russia and Serbia Hail Ties Amid Strained Relations with West," Irish Times, (January 17, 2019), retrieved from https://www.irishtimes.com/news/world/europe/russia-and-serbia-hailties-amid-strained-relations-with-west-1.3761914. On earlier hopes for Kosovo's economy benefiting from close collaboration with Turkey's see, Petrit Gashi, "Free Trade and FDI in Kosovo: Prospects for Integration into the EU and Turkish Production Networks," Turkish Economic Review, Vol. 4, No. 1 (2017), pp. 86-95.

48. Belgrade continues to make "normalization" impossible for Kosovo as efforts to be integrated into the larger world by way of membership to UNESCO, the United Nations more generally, and more recently Interpol reflects Vučićs recycling of old anti-Albanian positions that existed more than 20 years ago. Filip Rudic, "Rabid Anti-Albanian Sentiment Grips Serbian Media," BIRN, (May 16, 2017), retrieved from https://balkaninsight.com/2017/05/16/rabid-anti-albanian-sentiments-grip-serbian-media-05-16-2017/. These impediments to Kosovar integration have served as the pretext for periodic escalations like the current crisis over the "final" round of dialogue on which Brussels and Washington insists. Marta Szpala, "Hostages to Dialogue: The Process of Normalising Serbian-Kosovar Relations," OSW Commentary, No. 214, (June 8, 2016), retrieved from https://www.osw.waw.pl/en/publikacje/ osw-commentary/2016-06-08/hostages-to-dialogue-process-normalising-serbian-kosovar.

49. Perparim Isufi, "Rama Criticised for Albania-Kosovo 'Joint President' Idea," BIRN, (February 18, 2018), retrieved from https://balkaninsight.com/2018/02/19/albania-kosovo-joint-president-idea-unrealistic-analysts-02-19-2018/.

50. Emma Mawdsley, Warwick E. Murray, John Overton, Regina Scheyvens, and Glenn Banks, "Exporting Stimulus and "Shared Prosperity": Reinventing Foreign Aid for a Retroliberal Era," Development Policy Review, Vol. 36, (2018), pp. O25-O43. Many attached to the Clinton Administration have clearly profited from their close links to politicians whom they supported to secure power while in office. Leon Podesta, Madeline K. Albright, and Wesley K. Clark are some examples. Lura Limani, “Kosovo Lobbyists Linked to Panama Papers," Prishtina Insight, (April 8, 2016), retrieved February 2, 2019 from https://prishtinainsight. com/kosovo-lobbyists-linked-panama-papers/; Matthew Brunwasser, "That Crush at Kosovo's Business Door? The Return of U.S. Heroes," New York Times, (December 11, 2012), retrieved from https://cn.nytimes.com/world/20121217/c17kosovo/en-us/. 
51. Edi Rama, when mayor of Tirana, was constantly celebrated as the Western-vetted leader the Balkans needed. Jane Kramer, "Painting the Town: How Edi Rama Reinvented Albanian Politics," The New Yorker, (June 27, 2005).

52. Andrew Gray, "5 Takeaways from EU's Big Balkan Get-Together," Politico, (May 5, 2018), retrieved February 13, 2019, from https://www.politico.eu/article/eu-western-balkans-sofia-summit-takeawaysmembership-talks-enlargement/.

53. Visar Dizdari, Arjeta Troshani, and Elvisa Drishti, "The Bumpy Road of the Externally Transferred Austerity Agenda in Albania and Its Fragmentary Effects on Local Public Services," in Andrea Lippi and Tsekos N. Theodore (eds.), Local Public Services in Times of Austerity across Mediterranean Europe, (Cham: Palgrave Macmillan, 2019), pp. 193-216.

54. At a moment when negotiations with Brussels over progress towards Albania's integration into larger Europe stalled, Rama invited leaders of the three largest Albanian political parties in Macedonia. The gesture in late 2016 did have the effect of expediting the negotiations between Northern Macedonia and Greece, recently leading to a settlement over the formal naming of NATO's newest member. Fatjona Mejdini, "Macedonian Albanian Leaders Plot Joint Strategy in Tirana," BIRN, (December 30, 2016), retrieved from https://balkaninsight.com/2016/12/30/tirana-gathers-leaders-of-albanian-macedonian-parties-12-30-2016/.

55. Smoki Musaraj, "The Magic of Pyramid Firms: Cosmologies of Speculation, Repertoires of Credit and Collapsed Finance," Ethnos, Vol. 84, No. 2 (2019), pp. 179-200.

56. Anthony Clunies-Ross and Petar Sudar (eds.), Albania's Economy in Transition and Turmoil 1990-97, (New York: Routledge, 2018).

57. Afrim Krasniqi, "The Presidentialisation of Political Parties in Albania: Parliamentary Constraints," in The Presidentialisation of Political Parties in the Western Balkans, (New York: Palgrave Macmillan, 2019), pp. 169-192.

58. Gjergj Erebara, "Albania Students Spurn PM's Appeal for 'Dialogue,"' BIRN, (December 13, 2018), retrieved from https://balkaninsight.com/2018/12/13/albania-prime-minister-resist-yielding-to-student-requests-without-dialogue-12-13-2018/. For an accounting of what large numbers of civilians have been protesting in Albania see, Dizdari, Troshani, and Drishti, "The Bumpy Road of the Externally Transferred Austerity Agenda in Albania and Its Fragmentary Effects on Local Public Services," pp. 193216.

59. Arolda Elbasani and Senada Šelo Šabić, "Rule of Law, Corruption and Democratic Accountability in the Course of EU Enlargement," Journal of European Public Policy, Vol. 25, No. 9 (2018), pp. 1317-1335.

60. Gjergj Erebara, "Albanian Protests Channel Wider Anger with Rama Govt," BIRN, (December 11, 2018), retrieved from https://balkaninsight.com/2018/12/11/albanian-protests-channel-wider-anger-with-rama-govt-12-10-2018/.

61. Joseph Coelho, "Building State Failure in Kosovo," Contemporary Southeastern Europe, Vol. 2, No. 2 (2015), pp. 7-15.

62. Gëzim Visoka and Oliver Richmond, "After Liberal Peace? From Failed State-Building to an Emancipatory Peace in Kosovo," International Studies Perspectives, Vol. 18, No. 1 (2016), pp. 110-129.

63. Maj Grasten and Luca J. Uberti, "The Politics of Law in a Post-Conflict UN Protectorate: Privatisation and Property Rights in Kosovo (1999-2008)," Journal of International Relations and Development, Vol. 20, No. 1 (2017), pp. 162-189.

64. Andrea Lorenzo Capussela, State-building in Kosovo: Democracy, Corruption and the EU in the Balkans, (London: IB Tauris, 2015), pp. 66-79.

65. Daniel Serwer, From War to Peace in the Balkans, the Middle East and Ukraine, (New York: Palgrave Pivot, 2019), pp. 71-90.

66. Katarina Tadić and Arolda Elbasani, "State-building and Patronage Networks: How Political Parties Embezzled the Bureaucracy in Post-War Kosovo," Southeast European and Black Sea Studies, Vol. 18, No. 2 (2018), pp. 185-202. 
67. Perhaps the most charismatic iteration of the ongoing frustrations of Kosovars of varied political orientations was the satirical candidacy of Visar Arifaj and his Partisë së Fortë (Strong Party) during the 2013 elections. Calling himself the "Legendary President" to mock the level of political discourse in Kosovo, Arifaj's candidacy full of explicitly "ludicrous" declarations shed light on a vacuous political culture. The attention the mock campaign attracted was a telling moment, revealing even Kosovo's urban youth, long cultivated by neo-liberal institutions to serve as Kosovo's EU friendly future, had had enough. Edona Peci, "New Party Takes Ironic Swipe at Kosovo," BIRN, (June 27, 2013), retrieved from https://balkaninsight.com/2013/06/27/kosovo-s-strong-party-calls-for-pride-in-politics/.

68. Steffen Eckhard and Hylke Dijkstra, “Contested Implementation: The Unilateral Influence of Member States on Peacebuilding Policy in Kosovo," Global Policy Vol. 8, (2017), pp. 102-112; Patrice C. McMahon, The NGO Game: Post-Conflict Peacebuilding in the Balkans and Beyond, (Ithaca: Cornell University Press, 2017), pp. 124-156.

69. Michaela Strapacova, "The Reconciliation Process in Kosovo: Under the Shadow of Ethnic Primordialist Manipulation," Journal of Balkan and Near Eastern Studies, Vol. 18, No. 1 (2016), pp. 56-76.

70. Miruna Troncotă, '“The Association that Dissociates' - Narratives of Local Political Resistance in Kosovo and the Delayed Implementation of the Brussels Agreement," Southeast European and Black Sea Studies, Vol. 18, No. 2 (2018), pp. 219-238.

71. Maja Zivanovic and Die Morina, "Kosovo Albanians, Serbs Fear for Trepca Mine's Future," BIRN, (August 11, 2017), retrieved from https://balkaninsight.com/2017/08/11/kosovo-calls-political-serb-sstatements-on-trepca-mining-08-07-2017/.

72. I have made a similar argument about the reasons behind the war in Yemen. Isa Blumi, Destroying Yemen: What Chaos in Arabia Tells Us About the World, (Berkeley: University of California Press, 2018), pp. 201-212.

73. Bilge Yabancı, "Populism and Anti-Establishment Politics in Kosovo: A Case Study of Lëvizja Vetëvendosje," Contemporary Southeastern Europe, Vol. 3, No. 2 (2015), pp. 17-43.

74. Smoki Musaraj, "Corruption, Right On! Hidden Cameras, Cynical Satire, and Banal Intimacies of AntiCorruption," Current Anthropology, Vol. 59, No. S18 (2018), pp. 105-116.

75. Arta Sopi, “Kurti: Kosovo's 'Zombie Government' Cannot Last," Prishtina Insight, (January 29, 2019), retrieved from https://prishtinainsight.com/kurti-kosovos-zombie-government-cannot-last-mag/.

76. Katarzyna Kropiak, "The Politics of Nation-Building in Kosovo after 2008," Studia Środkowoeuropejskie i Bałkanistyczne, Vol. 26, (2018), pp. 135-150. 